\title{
entrevista
}

\section{“NÓS NÃO PRECISAMOS CONCORDAR COM OS GRITOS DA DIREITA, MAS NÓS PRECISAMOS, SE QUEREMOS SOBREVIVER, ENTENDER POR QUE ELES GRITAM E $O$ QUE ELES GRITAM"1}

\author{
Entrevista com Peter Demant ${ }^{2}$
}

\section{[Parte 1: Trajetória de Vida]}

\section{Revista Malala (RM)}

Após muitos anos lecionando no Brasil, você se aposentou pela Universidade de São Paulo e retornou à Holanda, sua alma mater. Sua trajetória foi marcada pela vivência também em outros lugares, como Israel. Como você avaliaria esta jornada frequentemente distante da terra natal e lecionando em outras línguas. Como é agora este movimento de retorno à Holanda?

\section{Peter Demant (PD)}

Passei minha juventude - a maior parte dela - fora do país em que nasci. Nasci em Amsterdã, mas dos 3 aos 18 anos morei na Bélgica. Minhas primeiras experiências, portanto, já foram fora do meu país natal.

Holanda e Bélgica são geograficamente próximas, mas são também muito diferentes e, naquela época, ainda existia um forte sentimento anti-holandês na Bélgica.

\footnotetext{
${ }^{1}$ Entrevista realizada via Google Meets, em 26/03/2021 com os entrevistadores da Comissão Editorial da Revista Malala: Cila Lima, Natalia Calfat e Ariel Finguerut.

2 Professor aposentado da Universidade de São Paulo (USP). Editor-chefe da Revista Malala; Autor, entre outros, do livro $O$ Mundo Muçulmano, Ed. Contexto, Sp. 2004. Em inglês, com o pseudônimo de Frank Emmanuel escreveu entre outros títulos o romance Martyr. Disponível na Amazon. Docente na Universiteit van Amsterdam. Link para o currículo lattes: http://lattes.cnpq.br/2604594578715465. ORCID: https:// orcid.org/0000-0002-1172-670X.
} 
Além disso, apesar de ter nascido na Holanda, perdemos muitos familiares no Holocausto, sendo a maioria na Holanda. Portanto, minha família ali ficou reduzida a uma fração do que era antes da II Guerra Mundial.

Eu sou de 1951. Ou seja, quando nasci já existia o Estado de Israel independente. Desde a minha infância, de certa forma, fui orientado a ir ao Estado de Israel, onde grande parte sobrevivente da família tinha se refugiado. Após o colegial na Antuérpia fui para Amsterdã para cursar a Universidade.

A opção de "voltar" à Holanda, onde na realidade tive quase nenhuma vivência anterior, se apresentou para o adolescente de então como um meio termo entre ficar na Bélgica ou migrar para Israel, à época visto como pouco seguro por causa do terrorismo palestino.

Mas Israel e toda a historia do Holocausto e da família que tinha ido para lá influenciaram meus estudos e meu percurso. Me formei como historiador especializado no conflito israelo-árabe e assuntos afins: Oriente Médio, fundamentalismos religiosos, etc. Passei por fases tanto hiper-sionistas quanto antissionistas, antes de pousar numa atitude (desconfortável, mas que até agora considero a mais honesta e justa) de "sionista crítico" simpatizando com ambas as nações politicamente sequestradas por suas alas extremistas). Em 1988 defendi meu doutorado sobre os assentamentos em Israel. Depois, já com quase 40 anos, migrei para Israel, onde encontrei uma posição como pesquisador sênior no Truman Institute for the Advancement of Peace, da Universidade Hebraica de Jerusalém, na época um instituto progressista.

Pesquisei os movimentos da paz israelenses, e depois trabalhei num deles: IPCRI (Israel/Palestine Center for Research and Information), na ocasião a única ONG completamente binacional israelo-palestina. Com o grandiloquente título de "project diretor" iniciei encontros entre pensadores e ativistas tanto judeus quanto árabes. Buscamos caminhos para aproximar nossos povos, fosse pela educação, conversas ou projetos comuns. Em 1996 organizamos um congresso internacional comparando as experiências de convivência entre Jerusalém e Bruxelas, ambas cidades mistas.

Israel não é um país fácil para se viver, seja judeu ou não. Para não judeus é obviamente bem mais difícil. Eu sempre fui exógamo, e não escolhi minhas parceiras particularmente por serem judias. Dessa maneira experimentei também as dificuldades pelas quais passam ali pessoas não judias. Eliane, ${ }^{3}$ minha esposa, foi discriminada e não conseguiu cidadania apesar do apoio de um tio meu que era cônsul da Holanda em Israel e de colegas da Universidade Hebraica. Portanto, apesar de eu ter um interessante trabalho; sempre houve um desapontamento em relação ao meu sonho juvenil sobre Israel. Eliane então me importou para o Brasil, por assim dizer (risos).

Eu me adaptei bastante bem ao Brasil, no círculo mais próximo, tendo sido bem recebido por diversas pessoas influentes. Vi que existia no país muito interesse sobre o Oriente Médio, mas pouca informação. Paulatinamente expandi então meu campo de pesquisa para o mundo do islã. Em seguida, para as relações entre o islã e o ocidente e, mais amplamente, as relações culturais internacionais. Nos anos de 2000 a 2007 dei Relações Internacionais na FASM (Faculdade Santa Marcelina e em 2001 entrei no Departamento de História da USP como professor visitante.

\footnotetext{
${ }^{3}$ Eliane Maria Rosenberg Colorni.
} 
Participei do estabelecimento do novo Instituto de Relações Internacionais e fui efetivado em 2003. Depois, em 2007, obtive minha livre-docência em História Contemporânea, com um estudo sobre as causas da supremacia histórica do ocidente.

O Brasil é um país que me acolheu com simpatia e minha experiência geral foi muito positiva, em vários aspectos. Antes de me aposentar da USP, tentei passar metade do ano dando aulas no Brasil e a outra metade na Holanda, mas as autoridades da Universidade - sem citar nomes - não gostaram da ideia. Então me aposentei, apesar que eu poderia ter continuado por mais alguns anos com este esquema. Optamos então por voltar para cá, inclusive porque minhas filhas do casamento anterior moram muito perto de mim aqui na Holanda. Contudo, não foram só essas ligações com a Holanda que pesaram. A cada ano eu percebia que a vida em São Paulo tornava-se mais complicada, perdendo qualidade, com menos segurança.

De volta à Holanda logo desenvolvi um trabalho muito agradável e interessante: dou aulas para alunos da terceira idade em várias universidades - Amsterdam, Rotterdam e Leiden. Esse conceito de exclusividade não existe aqui!! Reconectei com velhas amizades. E, claro, é inegável que a qualidade da vida, em muitos diferentes níveis, é extremamente melhor na Holanda do que no Brasil. Isso não surpreende.

\section{$\mathbf{R M}$}

A pergunta inicial tem um ponto interessante que é a dificuldade ou o desafio de lecionar em outra língua. Se você puder falar um pouco sobre isso. Você teve alguma dificuldade em organizar os autores? Ou outro tipo de dificuldade?

\section{PD}

Cheguei no Brasil em 2000. Meu primeiro curso na USP seria um convite do CEJ Centro de Estudos Judaicos da FFLCH sobre a política israelense. Poderia ser em inglês. Mas, de repente, um mês antes do início, me disseram que teria que ser mesmo em português. Eliane então me disse: "você fala italiano. Fale em italiano e tente aportuguesar um pouco". Nas primeiras aulas ela se sentou na primeira fileira para eventualmente traduzir algo, mas logo percebemos que os alunos ajudavam. Então diziam, "ah... professor você provavelmente quer dizer isto ou aquilo". Ou então: "Em português esta palavra é assim ou assado". E desta maneira, aos poucos, aprendi a me expressar.

Nos primeiros anos do IRI, no Instituto de Relações Internacionais da USP, os alunos desenvolveram e circularam entre si um "Vocabulário "Demant" ou de expressões "Demânticas" (risos). Se o professor Peter diz isto, então ele que dizer esta outra coisa. Felizmente, "consegui" uma destas listas e tentei integrar e corrigir os meus piores erros (risos).

\section{$\mathbf{R M}$}

Após sua mudança para a Holanda, você permaneceu dando aulas e oferecendo cursos sobre Oriente Médio, relações oriente e ocidente, islã e modernidade. Como você avalia, de forma comparativa, docentes, alunos e pesquisas em geral considerando os cenários no Brasil e na Holanda? Você poderia discorrer um pouco sobre potenciais diferenças nos interesses, conhecimentos, instituições, capital humano e infraestrutura? 
Como expliquei, estudei na Holanda. Minha graduação foi em História e depois fiz mestrado e doutorado. Em seguida, porém, houve um hiato de muitos anos provocado pela estadia em Israel e no Brasil. Em 2008 passei um semestre como professor visitante na minha própria alma mater, a Universidade de Amsterdã (UvA) - a maior e "secular", pois na verdade, existem duas universidades em Amsterdã, o que vai surpreender vocês, porque em São Paulo tem provavelmente 20 (risos).

Na UvA, na Ciência Política, em que lecionei por um semestre. foram dois cursos para alunos de graduação: um dos cursos foi sobre Israel e Palestina e outro sobre a América Latina - abusando do provérbio que, "no país de cegos, aquele com um olho é o rei" (risos).

0 que eu expliquei sobre Israel-Palestina para os meus alunos na Holanda foi basicamente a mesma coisa que disse para vocês em São Paulo. Mas em São Paulo eu era considerado "o imperialista de plantão" (risos) e, na Holanda, fui considerado "esquerdista". Naquela época, os movimentos estudantis brasileiros com quem tive contato na USP me fizeram sentir num "time warp". Quando eu fui aluno universitário nós também éramos impactados pelas ideias e pela paixão por Marx, Lênin ou Trotsky. Mas não se vê mais isto na Holanda - nem hoje nem há dez anos. Mesmo assim, eu, como professor, mantive meu conteúdo.

Ser considerado de direita ou esquerda não é algo que tira meu sono, embora eu me identifique mais com a esquerda do que com a direita. Mas na Holanda, nas últimas décadas, o público tornou-se mais conservador tanto na política quanto nas Universidades. 0 partido liberal-conservador há anos é maioria por aqui, enquanto que o partido trabalhista é apenas uma sombra do que era.

Por outro lado, quero frisar que, embora a intelectualidade e os alunos tenham talvez guinado para a centro-direita, a sociedade holandesa como um todo vem, no mesmo período, internalizando (e legislando sobre) muitos itens do programa da esquerda - pensemos em temas recentes como o meio ambiente e a mudança de clima, a diversidade, as questões da ética médica (direito ao aborto, eutanásia etc.).

Além do mais, existe já há muitos anos uma socialização e democratização do acesso à educação de qualidade, à assistência médica, aos programas culturais... bem mais avançadas do que no Brasil. Em outras palavras, os pontos de partida para comparar as duas sociedades são bem diferentes.

Na semana passada, tivemos eleições parlamentares aqui na Holanda e a direita reforçou sua maioria; e a esquerda, lamento dizer, está em declínio. Já no Brasil é verdade que há uma forte tendência conservadora reprimida - vocês têm o seu próprio Trump (risos). Se por um lado há uma força política conservadora, porém, uma grande parte dos alunos universitários no Brasil são progressistas e/ou de esquerda. Isto, na Holanda, não é mais o caso. Existem, obviamente, todos os partidos. Nós temos também partidos xenófobos, islamofóbicos e até com franjas antissemitas. Felizmente, eles estão ainda politicamente beyond the pale (além da fronteira da legitimidade) isolados... por enquanto. 
Agora mais concretamente: quais são as pesquisas, os recursos? Em geral, há na Holanda relativamente mais recursos por ser um país mais rico do que o Brasil. Mas não só por isso. É também um país que dá valor à pesquisa e ao ensino. Um país - e não o único na Europa - que oferece ensino publico de alta qualidade a todas as crianças (obrigatório). Assim essas crianças se tornam universitários já com uma bagagem de boa qualidade e existem opções de bolsas universitárias tanto para o ensino quanto a pesquisa. Resumindo: educação e pesquisa são consideradas elementos vitais de progresso para um país!!

Atualmente não tenho muito contato com as novas gerações, porque meu público são alunos acima de 50 anos. Esses cursos, apesar de aceitarem inscrições sem prova ou comprovante de estudos anteriores, são de alto nível. Portanto, os alunos precisam de uma certa formação para que consigam acompanhar os conteúdos. São oferecidos cursos sobre temas políticos, filosóficos, história da arte, arquitetura, psicologia, física quântica, entre outros. E são lotados. No ano passado em meu curso sobre a crise da civilização ocidental tive 100 alunos porque não cabia mais no anfiteatro (risos). Mesmo atualmente com o zoom, inscrições continuam a todo vapor com debates e perguntas de alto nível.

Em geral, os holandeses são menos emocionais do que os brasileiros e isto também aparece nas discussões que eu frequentemente tenho. Acho também que eles são, em geral, mais assertivos do que os brasileiros. No Brasil há mais emoção na comunicação. Às vezes, isto pode se tornar um ponto de fraqueza. Se fala muita coisa, mas na prática, na hora de implementar uma política, parece-me, muitas vezes, que a situação se torna problemática. Veja por exemplo a reação à pandemia. Nossa situação na Europa era inicialmente não muito melhor do que a do Brasil. Sei que a Europa tem instituições muito mais desenvolvidas do que o Brasil. Na área da saúde pública, aqui todos tem um seguro de saúde oficial, obrigatório e barato, já que cobre quase tudo que você precisa, de vacinas a cirurgias. Refugiados ou ilegais não têm essa cobertura, mas a Cruz Vermelha os ajuda. Em linhas gerais, o sistema funciona. Mesmo assim, se pensarmos no caso da Covid-19, a Europa está enfrentando dificuldades. As vacinações avançam devagar demais. Porem, não se compara ao Brasil pois há uma diferença básica no modo de vida das pessoas: não há favelas com cinco ou seis pessoas morando num quarto sem água corrente e sem esgoto!

\section{[Parte 2: A Europa em crise?]}

\section{RM}

A palavra "Europa" - tal como "Brasil" - desperta certas ideias no imaginário popular. Partindo do pós-Guerra Fria, a ideia de Europa é comumente associada à ideia de "Ocidente", de "Secularismo" de Organizações Políticas e Regimes Internacionais (como a ideia de uma União Europeia). Contudo, a realidade "europeia" tem sido diferente. Ainda existe, na sua leitura, uma ideia de Europa que os europeus estejam dispostos a defender? Autores contemporâneos como Douglas Murray e Ayaan Hirsi Ali apontam não só o declínio "ideológico" da Europa como indicam que uma certa "culpa" colonial tem acelerado este processo. Qual sua avaliação?

\section{PD}

Por acaso, eu estou dando também um curso para meus alunos da terceira idade que se chama: "A Europa... existe?" (risos). Mas minha resposta, após dois semestres em que eles precisaram sofrer comigo (risos), é que, sim, existe! Tanto a Europa quanto o 
Ocidente começaram, obviamente, como termos geográficos, mas se tornaram conceitos culturais. 0 Ocidente é mais amplo do que só a Europa. Há áreas do Ocidente que não pertencem à Europa. Sem dúvida, você pode incluir a Europa Ocidental no conceito do Ocidente. Sem dúvida, também, América do Norte (Canadá e EUA, pelo menos). Por outro lado, se consideramos por exemplo, a Rússia... os russos estão debatendo desde o czar Pedro o Grande se eles são europeus ou não! "Good luck with that”. No entanto, não pode se negar que eles fazem parte de uma civilização que compartilha muito com a Europa.

Você conhece Vladivostok, cidade perto do Japão, no Oceano Pacífico? Eu costumo mostrar para os alunos algumas fotografias de Vladivostok e os desafio: onde vocês pensam que esta cidade está localizada? Bom, eles dizem, talvez no Mar Báltico? Em algum lugar da Europa Oriental? (...). Então eu revelo e discutimos se ainda faz de certa forma parte da Europa. E a ideia do Ocidente também inclui os EUA, mas também, por exemplo, a Austrália e a Nova Zelândia que estão ainda mais a Leste da Europa do que Vladivostok. Mesmo assim a Austrália está culturalmente mais perto da Europa do que o Brasil.

Eu, pessoalmente, sou muito pró-europeu. Apesar de todos os problemas e crises pelos quais a Europa passa - inclusive crises ideológicas profundas - ainda tenho fé nas possibilidades futuras, na medida que pudermos universalizar a ideia da Europa. Mas o debate é aberto. Há aqueles que imaginam uma Europa entre fronteiras fechadas; há vozes e atores políticos que defendem tendências excludentes e xenófobas e querem fechar as portas para o resto do mundo. Alguns querem acabar com a própria União Europeia para voltar ao velho sistema dos Estados soberanos. É fácil concluir que isto não seria uma boa solução para os problemas que enfrentamos, nem para nós nem para o resto do mundo. Porém, não podemos negar que a União Europeia está em crise.

No primeiro semestre do curso analisamos a pergunta: “O que é a Europa?", “Quais suas realizações?". Apesar de tendências negativas que não devemos esquecer, enxergamos, em geral, uma história positiva repleta de êxitos. No segundo semestre lanço um desafio: tudo bem, essas realizações, mas nós estamos, mesmo assim, num mal-estar ideológico, num momento quando as ideologias e os valores que sustentavam o Ocidente parecem exauridos, não só a partir de críticas intelectuais chineses, africanos, anti-orientalistas, mas de dentro da própria intelectualidade europeia. Há uma forte influência de tendências pós-modernas e pós-coloniais que expressam uma forte crítica, que chega a rejeitar a Europa e o Ocidente em bloco. De onde ela vem? Como reagir?

Particularmente vejo isso relacionado à crise da esquerda. Pois na leitura mais ampla, a esquerda é aquela força que tende a introduzir mudanças progressistas em várias situações que limitam as possibilidades dos seres humanos e que exigem a transcendência dessas restrições em nome de direitos universais. Esta transformação encontramos não só na revolução francesa, mas também no renascimento, na revolução científica, no iluminismo... Todo o processo da modernização decorre desta força. Já a direita se define pelo oposto: é a tendência de conservar ou de voltar a um imaginário paraíso perdido. Muitas vezes trata-se, obviamente, de uma fictícia idealização do passado. É a dinâmica entre a direita e a esquerda que determina a história da Europa - pelo menos no último meio milênio.

E qual é essa crise? Os desapontamentos com as realizações da modernidade se traduzem em ataques à própria razão. Os horrores que acompanharam a revolução russa e o stalinismo resultaram na rejeição do socialismo e da própria possibilidade de uma 
sociedade mais justa. Sem falar nas injustiças maciças que os ocidentais fizeram contra populações inocentes e indefesas, de todo esse processo de escravização e de colonização dos povos nas Américas, e depois na África e na Ásia. E sem falar do holocausto dos judeus na II Guerra Mundial. Injustiças cometidas pelo ocidente, não raramente em nome da suposta superioridade de uma ou outra civilização ou raça, tornaram a ideia da universalização do progresso numa amarga piada.

Esses são os ingredientes da crise da esquerda. Ela faz, portanto, parte integral da crise da consciência europeia - se é que podemos falar nestes termos - e nos leva ao debate contemporâneo em torno de quem pode legitimamente participar na conversa sobre quem somos e para onde queremos ir como sociedade. Debate que inexoravelmente nos convida a falar da exclusão de minorias, de mulheres, de homossexuais, de raças.

Hoje esta conversa, que uma vez se iniciou em algum lugar europeu, é global.

Eu vejo Europa e Ocidente, portanto, como definições culturais tendo a ver mais com valores e cultura e menos com uma geografia específica.

Vocês talvez se lembrem que, às vezes, eu começava minhas aulas provocando nossos alunos da USP: 'Porque o Brasil não pode fazer parte da União Europeia?' Seria porque acidentes geográficos como um oceano nos separam para sempre? E, realmente, se você pensar a Europa (como a EU enfaticamente afirma), como projeto baseado na ideia de democracia liberal, nos valores de Direitos Humanos universais, eu não entendo por que este projeto não pudesse se expandir para outras regiões da Terra. Sim, a base do projeto foi meio utópica, mas, por outro lado, chegou a se concretizar de modo tangível e relativamente bem-sucedido (embora bastante burocrático) nos planos da cooperação econômica, jurídica, securitária e cultural. Por que este modelo não poderia se expandir para outras partes do mundo? Pois o futuro dos Estados soberanos nacionais, separados, dos quais nós temos 200 no mundo atual não é promissor. Eu não posso ver com grande otimismo a anarquia internacional, aceita pelos realistas como o normal permanente. Então, sim, o ideal é que a União Europeia se expanda. Esta expansão se condiciona a valores subjacentes compartilhados, que inevitavelmente são valores progressistas e universais. É nisto que ainda acredito.

A ideia de Europa está em perigo? Sim. Está com problemas. Felizmente, porém, apesar de todas as tendências "anti" entre grupos populistas tanto de direita quanto da esquerda (há também populistas esquerdistas, em geral euro-fóbicos), a maioria dos cidadãos europeus ainda é a favor do projeto europeu. 0 apoio gira, provavelmente, dependendo do país e do momento da pesquisa, em torno de 50 a $70 \%$ da população. Não é tão mau.

O impulso básico ainda está vivo. E por outro lado, eu não vejo como solução nenhum futuro alternativo baseado no nacionalismo. 0 programa das direitas proclama que precisamos sair da Europa. Espelha Trump que dizia "America for the Americans". Aliás, no caso dos EUA, o presidente Monroe já clamava "a América para os americanos" há 200 anos (risos). Nos 1820s o grito soou progressista. Hoje reflete o desejo de escapar do resto do globo.

Esses são programas excludentes, um tipo de egoísmo coletivo promovido por líderes blefando representar "o povo" que deve se defender contra o resto do mundo. São ecos 
de um mundo ao qual voltar nos imporia um preço alto demais. Os dilemas fundamentais da coexistência internacional são obviamente vinculados a quais valores compartilhamos. Contudo são menos os valores per se que nos dividem, pois acho que muitos destes valores, provavelmente, vocês e uma grande parte da humanidade também assinaria. A questão é como eles são aplicados, em particular onde eles se chocam, p.ex. quando mais igualdade conduz a menos liberdade, ou quando devemos delinear as prerrogativas do indivíduo contra as da coletividade.

Essas questões nos aproximam dos dilemas da razão instrumental, como também aparecem nas discussões de Adorno e Horkheimer e dos outros pensadores da Escola de Frankfurt. A razão é importante, mas se você se entrega só à razão instrumental, você abre o caminho para a barbárie. "Como posso estabelecer, da melhor maneira, uma fábrica que vai produzir x produtos? Como posso vender por tal e tal?". Sem uma racionalidade de valores, isso pode chegar a: "E como posso de maneira mais racional e mais eficaz exterminar meus inimigos?"

É exatamente a mesma maneira de pensar. Os nazistas contiveram a população antissemita na Europa oriental quando esta atacou judeus de forma selvagem e espontânea. 0 argumento nazista era "racional": "Chega de improvisação caótica e emocional! Precisamos fazer trens que irão para Auschwitz, calcular quantas pessoas cabem nos vagões, quantas podemos exterminar nas câmaras de gás por dia com qual quantidade determinada de químicos, etc."

Isso ilustra um tipo de razão desvinculada de valores. Weber fala da racionalidade instrumental, que está em contraste com a racionalidade dos valores. Se o Ocidente não conseguir fechar a ponte entre estas duas formas da razão, a crise vai se aprofundar.

\section{RM}

Posso só enfatizar dois pontos? 0 primeiro deles é: você falou bastante do declínio da esquerda, eu queria que você falasse um pouco sobre os valores liberais dentro da Europa (e aí pensando a Europa como um conceito, como você explicou). Como você explica, atores e governos defendendo posições não liberais, como por exemplo, contra pautas LGBT, casamento gay e, mesmo, a defesa da família tradicional, como por exemplo dificultar o divórcio e ir contra o aborto. Isso também, de certa forma, não é um declínio da Europa? 0 segundo aspecto, que eu gostaria que você falasse, é sobre a ideia de culpa colonial. Eu sei que o debate das artes é até um pouco secundário, mas eu vi um dia desses que a própria Holanda é um país que de certa forma está liderando essa devolução de obras de arte para outros países. Assim numa certa retração, de recuo, dessa posição que no passado era acusada de ser colonialista. Isso também, não é parte desta crise europeia?

\section{PD}

Temos que lembrar que as mulheres podem politicamente ser uma "minoria", mas na verdade, demograficamente, são a maioria. E as "minorias sexuais" todas juntas constituem talvez também uma maioria (só que ninguém ousa falar sobre este ponto). As restrições no comportamento privado e sexual fazem parte do ideário da direita. Porém, não são especificamente europeias. 0 oposto, as reivindicações da liberdade do indivíduo, fazem parte da pauta da modernidade, vinculada originalmente, como eu disse antes, à esquerda. 
A direita, neste esquema, tenta resgatar valores anteriores, ultrapassados pelo processo da modernização. Obviamente, porém, a realidade histórica é mais complexa. Na plena expansão do capitalismo no séc. XIX, os ingleses, protótipos da modernidade, foram vitorianos na sua moralidade. Mesmo assim, em termos gerais, a modernização tende a libertar as pessoas para expressar suas ideias, seus desejos, o que querem da vida. E à expressão seguem experimentação, visibilidade e finalmente, normalização do "anormal" de antes.

Quando os conservadores reconectam com os valores de uma sociedade pré-moderna baseada em obediência às tradições e à revelação divina, a tendência anti-feminina faz quase sempre parte do pacote. Porém isto não é especificamente ocidental. A anti-sexualidade, por exemplo, pode ser mais enraizada no cristianismo do que no judaísmo e no islã; mesmo assim a opressão da mulher existe no Islã e no judaísmo tanto quanto no mundo ocidental, embora as formas difiram. Você vai encontrar outros paralelos na China, no Mundo Muçulmano, na Índia e, em geral, em sociedades agrícolas pré-modernas. Precisaríamos confiar nas reconstruções duvidosas dos costumes de tribos pré-estatais para encontrar sociedades pré-modernas supostamente menos misóginas.

Quanto à questão colonial, obviamente, os europeus, os ocidentais, não podem negar que eles foram os conquistadores, espoliadores e opressores da maioria do planeta. Agora, claro, precisamos pagar nossas contas. Existem, porém, várias maneiras para fazer isso. Uma é dizer: por causa da nossa culpa ancestral, coletiva, nós, cujos antepassados fizeram tudo isso, não podemos mais abrir a boca. Deveríamos nos manter num silêncio envergonhado e deixar que os outros digam o que eles quiserem. Uma tal atitude logo chegará a absurdos.

Como exemplo uma pequena anedota: li na CNN que entre a população negra dos EUA há uma certa tendência, que também se expressaria em pressão social recíproca, de não realizar casamentos com brancos por causa da "honra racial". Agora, imagina se um alemão hoje dissesse algo deste tipo em público, sobre manter a honra da "raça ariana"?!... que aliás não existe: nenhuma raça existe como entidade essencial onde caraterísticas físicas acarretam qualidades mentais. São todas, em última instância, construções sociais. Considero o racismo reativo das vítimas tão nefasto e condenável quanto o protótipo racista original.

Eu acho que os europeus têm coisas para se envergonhar, os brasileiros têm coisas para se envergonhar, os chineses têm, os árabes também; mas todos temos também razões para sermos orgulhosos com as realizações positivas de nossos antepassados num passado mais distante ou mais recente, e que coletivamente constituem nosso legado comum. Em última instância, nós podemos nos considerar como herdeiros de realizações, que tudo que a humanidade realizou no passado.

É por isso que tenho problemas com certas tendências pós-coloniais, que visam dar espaço à auto expressão dos oprimidos ("subalternos"), facilitar a externalização de traumas como um passo para superar o que foi feito de destrutivo em nosso "centro íntimo". 0 impulso, positivo em si, pode acabar em exagero, e gerar uma "plataforma negativa" que apenas hostiliza os descendentes dos responsáveis de então e cria obstáculos à reconciliação.

A instrumentalização do status de vítima se encontra aliás em muitos contextos. Por exemplo, na maneira como Israel manipula às vezes o legado do holocausto: pode-se entender e talvez perdoar muitas coisas erradas que Israel faz, mas isto não desculpa para sempre a opressão dos direitos não menos válidos dos palestinos. A glorificação da vitimização tem um lado não positivo. 
Um tema caro à nossa linha editorial - que inclusive já foi tema de um número - é a liberdade de expressão. Teoricamente todos que vivem ou almejam viver numa democracia deveriam defender a liberdade de expressão como um valor fundamental. Todavia, o tema é sensível e polarizado. Não por menos, o ataque terrorista à sede do jornal satírico Charlie Hebdo em 2015 teve e ainda tem grande repercussão. Hoje me parece que o tema foi sequestrado pela "extrema-direita" ou por líderes populistas. Donald Trump foi em seu governo (2016 - 2020) proponente da tentativa de banir a entrada de muçulmanos nos EUA (alegando que a presença deles nos EUA aumentaria a ameaça terrorista) terminando - ele próprio - banido das grandes redes sociais, entre outros motivos, por incitar comportamentos terroristas e por disseminar notícias falsas que podem alimentar e mobilizar grupos violentos. Na sua leitura, como a instrumentalização da liberdade de expressão e seu uso na chamada "guerra cultural" tem contribuído para o cenário contemporâneo de crise da democracia liberal? Seis anos depois de atacar o Charlie Hebdo, o que o islã político aprendeu? Estão ganhando está "guerra" contra a liberdade de expressão?

PD

Não dá para proibir a expressão ou disseminação de um qualquer pensamento sem eventualmente arriscar a prática da livre expressão de opinião em geral. Você sabe onde começa, mas onde vai acabar? Há 200 anos o poeta Heinrich Heine profetizou: "Onde queimam livros, ao final queimarão seres humanos". A liberdade de expressão permanece a pedra angular da democracia liberal.

Tendo dito isso, acho que na conjuntura atual as ameaças à liberdade de expressão vêm mais de uma certa esquerda do que da direita. Não me vêm à mente muitas tentativas direitistas recentes para censurar ideias - exceto em casos de regimes conservadores pseudo-autoritários como a Polônia, onde a mera menção de colaboração de antissemitas poloneses no Holocausto é considerada como "ataque à honra nacional". As tentativas de Trump para banir a entrada de muçulmanos nos EUA foram odiosas, mas têm mais a ver com liberdade de mobilidade do que com a da expressão. Este - talvez o pior presidente na história dos EUA - é um atacadista de falsas notícias, mas, novamente, falamos em demagogia, não em censura. A especialidade da direita hoje é mais inundar o mercado das ideias com fake news, informações fantasiosas e teorias conspiratórias do que em ativamente frear a expressão das ideias de seu oponente.

Pelo contrário, encontramos na esquerda pós-moderna a tendência para privilegiar a representação acima da própria realidade externa, já que o relativismo considera esta última como ou inerentemente inatingível, "múltipla" ou inevitavelmente tingida a priori de preconceitos. Ou até inexistente! Tal perspectiva, hoje influente na esquerda, tem fomentado a cultura do cancelamento, cuja origem na luta pela justiça é admirável, mas que desemboca em absurdos. Quem ousa ainda assistir em público a filmes de "pedófilos" como Woody Allen ou Roman Polanski? Você ainda arriscaria ler Harry Potter, a "detestável" obra da transfóbica J.K. Rowling? O famoso jornalista e intelectual público Ian Buruma foi tirado da New York Review of Books por ter publicado um artigo de um autor crítico do movimento MeToo. E como uma atriz judia branca como Gal Gadot ousa representar a rainha egípcia "negra” Cleópatra? É pura apropriação cultural! 
E a censura politicamente correta de "valores errados" não para no presente: retrospectivamente deslegitima e tenta censurar também "criminosos" históricos tais como o pintor Paul Gauguin ("voyeurista"), o filósofo Immanuel Kant ("racista"), ou o compositor Mozart ("islamófobo"). Assim a história degenera em relatório de tudo o que não deveria ter acontecido! Esta "estratégia" ridícula só vai conduzir a um beco sem saída.

Não acho que os ataques jihadistas ao Charlie Hebdo conseguiram um retrocesso na liberdade de expressão na França. Recentemente um islamista extremista decapitou um professor de escola publica por ter mostrado aos alunos as charges de Charlie - ora, a reação tem sido antes uma mobilização $a$ favor das liberdades civis! É verdade que aqui e ali observamos também reações mais preocupantes, mas por enquanto ainda não vi vitórias islamistas impressionantes - fora da própria comunidade deles.

A luta contra ideias que consideramos errôneas deve-se travar por argumentos e não por calar a boca do adversário. Portanto eu sou a favor de uma quase ilimitada liberdade de expressão - incluindo até mentiras perigosas como a negação do holocausto! com a única exceção de apelos à violência. Estes devem ser reprimidos.

\section{[Parte 3: Pandemia e o OMMM em transformação]}

\section{$\mathbf{R M}$}

0 tema Israel - Palestina lhe é caro e nós sabemos. Os jovens de hoje tendem a simpatizar com os palestinos e Israel tem, recentemente, buscado e mantido diálogos e projetos de cooperação com líderes autocráticos. Qual sua análise da conjuntura geopolítica Israel-palestina? E como Israel tem usado sua resposta aparentemente eficaz à pandemia como um "soft power" para tentar melhorar ou mesmo manter a imagem de uma potência regional?

\section{PD}

Obrigado pela pergunta, mas tenho que advertir que você está apresentando aqui uma maçã envenenada, que precisaria de uma exposição mais aprofundada do que é possível aqui sem arriscar desmaiarmos antes da sua conclusão (risos). Primeiramente, a cooperação recente com líderes autocráticos não é nada de novo para Israel, que, no passado, já cooperou com ditadores africanos, latino-americanos e outros. Trata-se de uma aplicação da estratégia que Israel desenvolveu já meio século atrás. Haja visto o boicote dos países árabes (que amplamente continua) e a ausência de relações diplomáticas, econômicas ou até culturais com o mundo árabe circundante. Israel busca "saltar acima da muralha árabe" em busca de potências com quem cooperar e se fortalecer. Por exemplo, a Turquia, no passado amiga de Israel, ou o Irã, com quem teve uma boa relação num passado mais distante ainda, quando o Xá da Pérsia foi amigo de Israel. Mas tudo isso não é nada de muito original. Embora eu não aplauda, todos os países fazem isso, às vezes é inevitável tecer relações com regimes não democráticos ou "tiranos amistosos".

Vejo, no entanto, outros pontos bem mais fundamentais. Israel passa há pelo menos 20 anos por um processo de deslegitimação ideológica internacional. No nível das opiniões públicas, a conviç̧ão de que, como país, Israel não deveria mais existir, é hoje 
provavelmente mais difundida do que antes. 0 perigo é que, mais cedo ou mais tarde, os governos sigam as preferências de sua base. Isto, obviamente, não deixa a população israelense muito feliz. De modo geral, a esquerda apoia a causa palestina. A identificação é compreensível, já que os palestinos são o lado mais fraco, são as vítimas. Mas mesmo se vítimas, eu como sionista crítico, ainda definiria os palestinos como "as vítimas das vítimas". Isto criou uma situação bem idiossincrática, complexa demais para esquemas simplistas anti-imperialistas. Hoje a simpatia com os palestinos, outrora invisíveis, é generalizada com forte respaldo entre intelectuais de esquerda. Por outro lado, vários grupos populistas xenófobos da direita na Europa e nos EUA mantêm uma relação não menos ambígua com o sionismo. São sempre e, em primeiro lugar, anti-imigrantes, anti-muçulmanos, mas, não raramente, também antissemitas. Há até aqueles que, como o Partido Trabalhista na Inglaterra de Jeremy Corbyn, combinam posturas esquerdistas com uma retórica e insinuações antissemitas.

Ao mesmo tempo, o velho "tradicional" antissemitismo da extrema-direita não desapareceu. Aparece na França, por exemplo no velho Jean-Marie Le Pen (o pai de Marine) Le Pen ou em Viktor Orbán, em pleno poder na Hungria. Eu poderia acrescentar mais à lista. Israel, apesar das suas divergências internas, é ainda forte "em casa". Mas, "na rua", a situação começa a preocupar.

Naturalmente, muitas das críticas a Israel são justificadas. Temos ali racismo, opressão aos palestinos, além de muita indiferença entre os judeus israelenses. Mas obviamente Israel não é um país de Deuses nem de Demônios. É um país de seres humanos com fraquezas e pontos positivos. Como todos nós, em todos os lugares. 0 inegável crescimento do antissemitismo no mundo soa para muitos israelenses como uma justificativa a mais para o projeto sionista. É difícil argumentar contra isso.

A força e a capacidade de mobilização na cena internacional das quais Israel hoje ainda dispõe, decorrem, porém, mais da sua força militar e econômica do que da aceitação da sua legitimidade. A erosão desta legitimidade ajuda a direita em Israel. A direita israelense por sua vez aprofunda as exatas políticas que ainda mais erodem a legitimidade. Os tristes resquícios da esquerda sionista enfrentam uma tarefa tipo "mission impossible" de tirar o Estado judeu de seu imbróglio destruidor.

Quanto à postura Israelense na pandemia, deve-se admitir que Israel merece admiração por ser realmente bem mais eficaz do que a grande maioria dos outros países. Mas - deveria ser supérfluo enfatizar - não vacina milhões de pessoas para fazer êxito na política externa. Inocula para proteger sua própria população. A política de vacinação mostra a discrepância enorme em termos de desenvolvimento entre o Estado de Israel (que aliás também vacina os cidadãos árabes israelenses, ou seja os palestinos israelenses) e todos os outros países da região. Não acho que esta discrepância seja para sempre impossível de superar. Mas, no momento, ainda existe. Mas a realidade é também que Israel, já por anos, por exemplo, na Guerra civil na Síria, vez ou outra, dava ajuda humanitária às vítimas civis sírias, que são transportadas para hospitais em Israel e tratadas dos ferimentos de guerras.

Israel não ganha muitos pontos na opinião pública internacional por causa disso: a maioria das pessoas não presta atenção; eles não fazem isto por motivos propagandistas, mas como gesto humanitário. 


\section{$\mathbf{R M}$}

Parte da mídia, até os recentes acontecimentos da semana do dia 12/05/2021, mantiveram congeladas as notícias sobre os conflitos no Oriente Médio. No entanto, os atores (EUA, Israel, Arábia Saudita, Irã e Rússia) não mudaram suas agendas. 0 que você poderia mencionar sobre os conflitos israelo-palestinos atuais?

\section{PD}

Cabem aqui três observações. A primeira, que o conflito entre Israel e o mundo árabe-israelense está, pelo menos em termos propagandísticos, diminuindo. Ninguém mais presta atenção. A negligência facilita o projeto objetivamente colonial da direita sionista: subjetivamente os colonos na Cisjordânia podem não se sentir colonizadores, mas dentro da realidade de soma zero onde ambos os lados inimigos operam, os assentamentos israelenses dificilmente se entendem de outra forma. A anexação rastejante do território palestino por sua vez explica o dilema palestino, pois, momentaneamente, os foguetes do Hamas tornam a violência estrutural de Israel algo visível e internacionalmente relevante. Logo, porém, as represálias israelenses punem a população palestina civil ainda mais; impõe-se cessar-fogo recíproco, e o conflito volta a seu costumeiro perfil baixo. Conclusão: tanto aqui quanto do outro lado da colina, miséria humana totalmente fútil!

Mas, e isto é fundamental, qualquer que seja seu perfil, o conflito não acabou - apesar dos chamados Acordos de Abrão com os Emirados e com o Bahrein, a da tendência de normalização com o Marrocos e até com a Arábia Saudita. Obviamente, eu apoio na medida em que uma paz injusta é melhor do que uma guerra justa. Mas esta paz é oportunista. Reflete uma exaustão da militância árabe, sem nenhuma conciliação. Enquanto nós não temos conciliação, teremos este conflito.

Em segundo lugar, Israel está sujeito a um tipo de decadência ideológica que mesmo eu tenho dificuldade para entender. Começou, ao mais tardar, com o fracasso do acordo de Camp David em 2000 entre Bill Clinton, Yasser Arafat e Ehud Barak. Este fracasso produziu uma tendência de declínio da esquerda israelense. Quando tento entender, enxergo uma certa dualidade. Por um lado, os israelenses acusam "os palestinos não querem a paz, portanto, nós não podemos ter a paz com eles". Realmente nas últimas décadas o Hamas, hoje o maior partido palestino, fez tudo o que podia para comprovar este ponto de propaganda israelense. Dá para encontrar tendências mais moderadas, mas eles são desapontadas e estão bem escondidas. 0 Hamas é ainda um movimento islamista antissemita imbuído de um complexo de martirização. A lógica é "Não importa que nosso povo sofra, se podemos fazer o outro povo sofrer ainda mais." 0 resultado: há israelenses que pensam: "nós não podemos ter a paz", e outros que pensam: "nós não precisamos da paz". A direita sionista pode se gabar com: "apesar de todo o barulho que o inimigo faz, somos sempre nós que vencemos as guerras."

E eles têm razão. Graças ou devido à indiferença internacional, Israel simplesmente não paga o preço pela ocupação da Cisjordânia e do assédio de Gaza. Acho uma pena dizer isso: não estou de acordo nem com a estratégia $B D S$ (movimento que prega o Boicote, o Desinvestimento e Sanções contra Israel) nem com seus objetivos. Mas, neste ponto, eles não deixam de ter razão. BDS diz: Israel não faz nenhum movimento para a paz, pois não sente que tem algo a ganhar com a paz ou a perder continuando a colonização dos territórios palestinos. Então o resultado desta tendência é: "por que fazer o esforço?" Israel 
mergulha assim em temas domésticos, culturais ou econômicos tais como a posição dos ultraortodoxos na sociedade, o custo de vida, os impostos etc. E os palestinos simplesmente desaparecem como item político. Temo que isso continue até os peaceniks de ambos os lados reverem suas estratégias.

Neste momento, dentro do campo da direita, Netanyahu, a quem eu detesto, vocês sabem (risos), absurdamente tem se tornado o mais moderado "esquerdista" dessa coalizão da direita que ele repetidamente conseguiu construir. Os palestinos também não fazem muito pela paz. Eu simpatizo, tenho compaixão com os palestinos, mas eles continuam, como os israelenses, presos à sua estrutura ideológica. Difícil sair dela. Mas, e isto é a terceira observação, nem os palestinos escapam de suas próprias armadilhas ideológicas. Por um lado há o "você não pode fazer (ainda mais) concessões". Ir contra os princípios sagrados da luta justa seria uma traição. Quem fala em concessões arrisca uma bala na cabeça. Qual seria então a saída: o Estado binacional, com implementação do direito de retorno dos refugiados palestinos, ab-rogação da Lei do Retorno para judeus, mas plenos direitos iguais para ambas as nações. Este projeto é totalmente utópico. Soa mais como uma reformulação sofisticada para legitimar a reconquista árabe e/ou muçulmana do que como convida sincera à conciliação. Portanto, repele a grande maioria dos judeus tanto israelenses quanto na diáspora. Entre esses dois polos retóricos opostos, não há nenhuma política de passos intermediários. Logo, nesta terra ideologicamente arrasada, os partidos palestinos usam a instabilidade do conflito de forma oportunista. Muitos são políticos corruptos que não servem realmente aos interesses de sua própria população.

Eu não vejo claramente como escapar deste círculo vicioso. Quando os leitores lerem estas palavras, elas estarão provavelmente já ultrapassadas pela realidade política. No momento atual, contudo, coloco minha esperança na nova coalizão israelense da "Mudança" que engloba sete partidos opostos (entre eles, um islamista palestino!) num projeto comum para derrotar a corrida para a catástrofe. Num conflito tão complexo, quiçá a salvação chegue do lado mais improvável?

\section{$\mathbf{R M}$}

Peter, gostaria de fazer suas considerações finais?

\section{PD}

0 quadro que esbocei acima nos permite tirar uma lição para os progressistas no conflito Israel - Palestina, mas vale também para o debate ideológico sobre a Europa. Ao abrir os jornais e as mídias, encontramos cada vez mais propósitos negacionistas e odiosos de uma direita radicalmente excludente da diversidade. Nós não precisamos concordar com os gritos da direita, mas se queremos sobreviver, precisamos entender por que eles gritam e o que eles gritam. Isto não é tão fácil como soa. Mas não há outra saída. 